\title{
Clinical presentation and predictors of survival related to extent of bone metastasis in 900 prostate cancer patients
}

Rami Klaff, Eberhard Varenhorst, Anders Berglund, Per Olov Hedlund, Folke Sjöberg and Gabriel Sandblom

\section{Journal Article}

\section{Tweet}

N.B.: When citing this work, cite the original article.

Original Publication:

Rami Klaff, Eberhard Varenhorst, Anders Berglund, Per Olov Hedlund, Folke Sjöberg and Gabriel Sandblom, Clinical presentation and predictors of survival related to extent of bone metastasis in 900 prostate cancer patients, Scandinavian journal of urology, 2016. 50(5), pp.352-359.

http://dx.doi.org/10.1080/21681805.2016.1209689

Copyright: Informa Healthcare

http://informahealthcare.com/

Postprint available at: Linköping University Electronic Press

http://urn.kb.se/resolve?urn=urn:nbn:se:liu:diva-132207

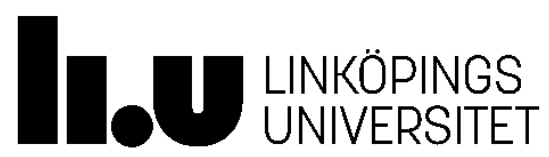




\section{ORIGINAL ARTICLE}

Clinical presentation and predictors of survival related to extent of bone metastasis in 900 prostate cancer patients

RAMI KLAFF $^{1}$, EBERHARD VARENHORST ${ }^{1}$, ANDERS BERGLUND ${ }^{2}$, PER OLOV HEDLUND ${ }^{3}$, FOLKE SJÖBERG ${ }^{4}$ AND GABRIEL SANDBLOM ${ }^{5}$ \& THE SPCG-5 STUDY GROUP*

${ }^{1}$ Department of Urology, and Department of Clinical and Experimental Medicine, Linköping University, SE-581 85 Linköping, Sweden.

${ }^{2}$ EpiStat, SE-756 55 Uppsala, Sweden.

${ }^{3}$ Department of Urology, Karolinska Institute, SE- 17177 Solna, Sweden.

${ }^{4}$ Department of Clinical and Experimental Medicine, Linköping University, SE-581 85 Linköping, Sweden.

${ }^{5}$ Department of Clinical Sciences, Intervention and Technology (CLINTEC), Karolinska Institute, Centre for Digestive Diseases, Karolinska University Hospital, SE-141 86 Stockholm, Sweden.

*A complete list of the members of the SPCG-5 study group is given in the Appendix

Corresponding author: Rami Klaff, Department of Urology, Linköping University, S 58185 Linköping Sweden. Tel.: 0046736571918 Fax: 0046101033777

E-mail addresses: $\underline{\text { Rami.Klaff@gmail.com }}$

Running title: Survival related to extent of bone metastases 


\begin{abstract}
Objective. The impact of bone metastasis on survival and quality-of-life in men with hormone-naïve prostate cancer is not fully understood. Material and methods. Nine hundred patients from the randomised trial (No.5) by the Scandinavian Prostate Cancer Group, comparing parenteral oestrogen with total androgen blockade. Extent of bone metastasis was categorised according to a modified Soloway score: Score $1 n=319$; Score $2 n=483$; Score 3 $\mathrm{n}=98$ patients. The primary outcome measurements were mean differences in quality-of-life and overall survival. Results. Quality-of-life rating scales showed a decrease with increasing extent of bone metastasis $(\mathrm{p}<0.001)$. The mean global health status decreased from 64.4 to 50.5 for Soloway score 1 and 3, respectively. Following adjustment for performance status, analgesic consumption, grade of malignancy, alkaline phosphatase, PSA, haemoglobin and global health status, Soloway score 2 and 3 had a 47\% (HR 1.47, 95\% CI 1.21-1.80) and 78\% (HR 1.78 95\%, CI 1.32-2.42) increased mortality respectively compared to Soloway score 1. Independent predictive factors of mortality were assessed. Conclusions. Patient grouping based on three categories of extent of bone metastasis related to performance status, haemoglobin, and global health status at presentation, as independent predictors of mortality, may provide improved accuracy of prognosis.
\end{abstract}

Key Words: androgen deprivation treatment, bone metastasis, extent of disease, hormonenaïve, predictors of survival, prostate cancer 


\section{Introduction}

Prostate cancer is the most commonly diagnosed male cancer in Scandinavia and most other western countries, where 10,452 incident cases were diagnosed in Sweden 2014[1]. Although the introduction of PSA as a diagnostic tool at the end of the last century has led to a marked stage migration of the disease with an increasing proportion of prostate cancer cases being diagnosed at a clinically localised stage, many men still have distant metastases at diagnosis (12\% in Sweden in 2014) [1]. Once the tumour has metastasised the disease is practically incurable, albeit many men live for several years with generalised prostate cancer [2, 3]. Because of variations in clinical background, survival following standard androgen deprivation treatment (ADT) varies greatly [4]. Metastases most frequently (>90\%) involve the bone, and the extent of these metastases at diagnosis has a great influence on the patient's fate [5].

Traditionally, radionuclide imaging of the skeleton with measurement of bone uptake is used to diagnose metastatic bone involvement [6]. Soloway and co-workers proposed a graded classification of extent of bone metastasis, estimating the number and size of bone metastases prior to treatment [7]. By quantifying the extent of metastasis to the bone, a better prediction of survival was achieved than when relying on M1b-categorisation alone.

Recent clinical trials tested a new concept of systemic therapy for hormone-naïve metastatic prostate cancer and it was shown that chemo-hormonal therapy, i.e. six cycles of docetaxel at the beginning of ADT, resulted in significantly longer overall survival than ADT alone [810]. The clinical benefit was particularly pronounced among patients with high-volume disease. 
In this context it is important to identify which patients are likely to benefit from a new treatment modality, and to accurately distinguish these from the rest.

At present it is not fully clear how great the impact of bone metastasis at diagnosis is on pain, fatigue, deteriorated performance status and other clinical variables.

The aim of this study was to investigate the prognostic significance of the extent of bone metastasis in relation to other pre-treatment variables, and to explore the impact of bone metastasis on quality-of-life.

\section{Material and methods}

The SPCG 5 Trial. The cohort of 900 men in this study was derived from a prospective phase III non-inferiority clinical trial (No 5) conducted by the Scandinavian Prostate Cancer Group (SPCG). Primarily, 915 patients with hormone- naïve metastatic prostate cancer from 61 centres in Denmark, Finland, Iceland, Norway and Sweden between December 1992 and June 1997 were included [11, 12]. To be eligible, patients were required to have bone metastases (M1b) and an Eastern Cooperative Oncology Group (ECOG) performance status of 0-2. The primary objective of the SPCG trial was to determine whether or not survival with high dose parenteral oestrogen therapy was inferior to that with TAB.

Serum concentrations of PSA and total alkaline phosphatase (ALP), and haemoglobin levels were determined by routine laboratory testing before the start of treatment.

Bone scanning and categorisation. The bone uptake of 99m technetium MPD was assessed in all patients according to local standard algorithms at each participating centre. Bone scans with multiple disseminated areas of increased activity were considered diagnostic of multiple metastases. 
The extent of metastasis determined on bone scan was quantified according to a modified Soloway score (mSS) with three categories according to the extent of metastasis: Score $1=$ the total area of hot spots less than three bodies of a lumbar vertebra; Score $2=$ the total area of hot spots larger than Score 1 , but $<75 \%$ of the total scan; and Score $3 \geq 75 \%$ of the total scan or super scan [7]. In 15 cases the extent of bone metastasis was not recorded, leaving 900 patients eligible for inclusion in this study.

Quality-of-Life. The European Organisation for Research and Treatment of Cancer Qualityof-Life Questionnaire-C30 version 1 (EORTC-30) was used to evaluate quality-of-life (QoL) [13]. The questionnaire was designed to be cancer-specific and has been utilised in several international clinical trials. It is available in Danish, Swedish, Norwegian and Finnish translations. The questionnaire is appropriate for self-administrations and consists of 30 items, including nine multi-item scales, five functional scales, three symptom scaled and a global health status scale and single items, adding up to a total of 15 ratings. The raw scores from the questionnaire were linearly transformed into a standardised 0-100 scale score.

Follow-up. The men included were scheduled for follow-up one, three and six months after start of the study and thereafter every six months. Time to death was determined from the date of treatment initiation.

Ethics. The study was performed in accordance with the recommendations of the Helsinki Declaration and approved by the ethics committees of all centres partaking in the study. Patients were given verbal and written information, and gave their informed consent to be included in the study. 
Statistical methods. In the study cohort of 900 men, the extent of bone metastasis was graded according to the mSS. Clinical characteristics were sorted according to mSS. The mean values of EORTC-30 ratings at baseline related to extent of bone metastasis were tested by analysis of variance (ANOVA). The primary outcome was overall survival. Survival was defined as the interval between the date of inclusion and the date of death or end of follow-up, whichever came first. Two patients in the mSS 1 group had no valid follow-up information. Cumulative overall survival related to extent of bone metastasis was assessed using Kaplan-Meier curve analysis. A univariate Cox regression model was then used to assess the risk for death according to the mSS. In a next step, the mSS and each clinical characteristic were included in a stepwise Cox regression model (treatment, age, cancer-related pain, ECOG performance status, analgesic consumption, grade of malignancy, T-category, cardiovascular comorbidity, ALP, PSA, haemoglobin, testosterone, quality of life). The clinical variables that had a confounding impact on the estimation of mSS were included in the final multivariate regression model. In order to identify independent predictors within the mSS groups, multivariate Cox regression models were constructed using all variables that were statistically significant in the univariate analyses, stratifying for mSS. In the sensitivity analyses, mSS 2 and 3 were aggregated into one group and the univariate and the multivariate analyses were repeated. In a subsequent step, we repeated all the survival analyses considering cancerspecific mortality only. All p-values were two-sided and statistical significance was considered at $\mathrm{p}<0.05$. All analyses were performed using the $\mathrm{R}$ version 3.1.1.

\section{Results}

Baseline characteristics for the 900 patients enrolled in the study cohort are presented in table 1 as groups according to the extent of bone metastasis (Soloway score). Most men had Score 2 at inclusion (53.7\%). The median follow-up was 75.6 months (39.2-139.3 months), during 
which 841 men died. Median follow-up was shorter with a higher mSS. Cancer-related pain, analgesic consumption, T-category, ALP, PSA, and haemoglobin were all differed significantly between the mSS groups (Table 1).

The mean global health status decreased from 64.4 to 50.5 at mSS 1 and 3, respectively (Table 2). Four of five functioning scales showed decreased rating with increased mSS; mean physical functioning was 81.4 for Score 1 and 65.7 for Score $3(\mathrm{p}<0.001)$. Most symptoms, including fatigue, pain, and insomnia were significantly more pronounced in patients with a higher mSS (Table 2).

Overall survival was higher among patients with mSS 1 at inclusion (5-year 39\% 95\% CI 3445\%) compared to those with Scores 2 (5-year 17\%, 95\% CI 14-21\%) and 3 (5-year 9\%, 95\% CI 5-17\%), respectively. This was also confirmed in a univariate Cox Regression model (Figure 1a). Following adjustment for performance status, analgesic consumption, grade of malignancy, ALP, PSA, haemoglobin and global health status, mSS 2 and 3 had a 47\% (HR 1.47, 95\% CI 1.21-1.80) and 78\% (HR 1.78, 95\% CI 1.32-2.42) increased mortality compared to Score 1, respectively (Figure 1a). The same pattern was observed when limiting to cancerspecific mortality (Modified Soloway Score 2 - HR 1.75, 95\% CI 1.39-2.20; Score 3 - HR 1.96, 95\% CI 1.39-2.72) (Figure 1b).

Independent prognostic factors associated with overall mortality risk according to extent of metastasis were defined using multivariate Cox regression analysis (Table 3). Poor performance status, high analgesic consumption, high grade of malignancy and high level of PSA were all independent risk factors for mortality in patients with mSS 1 . On the contrary, a high haemoglobin and good global health status were both associated with lower mortality in 
patients with mSS 1. In patients with mSS 2, poor performance status, high grade of malignancy and elevated ALP were independent risk factors, while a high haemoglobin and good global health status were independent factors for lower mortality (Table 3). In the mSS 3 group, only the level of haemoglobin had a significant impact on mortality (Table 3).

In the sensitivity analyses, performance status, ALP, haemoglobin, and global health status were all independent prognostic factors of overall mortality when Score Groups 2 and 3 were taken together. In an analysis limited to cancer-specific mortality, grade of malignancy and PSA level were independent predictive factors for mSS 1. Base-line demographic and disease characteristics were similar between treatment groups. No significant differences in overall or disease specific survival were observed and thus, treatment was not included in the multivariate models. Data on quality of life prior to start of endocrine treatment and during treatment were obtained from all patients but not analysed according to the different forms of treatment [14]. Performance status, grade of malignancy, ALP, and global health status were independent predictive factors for mSS 2 group, whereas in the Score 3 group haemoglobin level was the only predictive factor.

\section{Discussion}

This study confirms the importance of quantitative assessment of the extent of bone metastasis in men with M1b prostate cancer. The extent of bone disease, according to the mSS, had a crucial impact on expected quality-of-life and survival. The subgroups of men with widespread metastasis but without performance status deterioration are probably those that benefit the most from combined endocrine treatment with chemotherapy. Although all men in the present study had bone metastases, they had reached different levels in the metastatic process at diagnosis. In the present study a mSS was constructed with three 
score categories based on visual estimation of the total area of lesions on bone scan images. Originally, Soloway and co-workers graded the extent of the disease into four categories. Their original grading system showed significant associations with survival for Scores 1 and 4, but Scores 2 and 3 did not differ significantly [7]. Therefore, the original Soloway Scores 2 and 3 included as Score 2 in the modified Solowey Score of the SPCG 5 trial. Using recursive partitioning of several variables Glass et al. developed three prognostic groups that were significantly predictive of overall survival [15]. Their 5-year overall survival was very similar to our estimates for Score Groups 1, 2 and 3: 42\%, 21\% and 9\% respectively.

The validity and clinical relevance of the criteria for the prognostic grouping of Glass and coworkers were corroborated by a significant difference in overall survival between the good and intermediate and the good and poor prognostic groups. However, the difference between the intermediate and poor prognostic groups was not statistically significant [16].

A number of large randomised clinical trials of ADT in hormone-naïve metastatic prostate cancer, summarised in table 4, have reported the extent of bone metastasis to be an important mortality risk factor. In the crude time to event analysis we included all the baseline characteristics within each group of mSS (Table 1). In a next step we only included the baseline characteristics that had statistically significant impact on mortality in the crude analysis into the multivariate models.

When reviewing independent prognostic factors at diagnosis for patients with M1 disease, performance status, extent of bone metastasis, Gleason score, and ALP level are the most important measures previously identified. Other variables, such as age at diagnosis, pain, 
analgesic consumption, T-category, haemoglobin, PSA level, and testosterone levels are less frequently stated in the literature as being significant prognostic factors [17].

Data with respect to QoL in patients with untreated metastatic prostate cancer are limited[18]. Most attention has been paid to the QoL in prostate cancer patients with localised disease [19]. Our study shows significantly poorer QoL with increasing extent of metastasis. These results are in accordance with Rosenfeld et al concluding that higher cancer stage appears to be associated with poorer QoL in prostate cancer [20].

ALP is widely used as a marker of skeletal involvement in prostate cancer. Elevated ALP was significantly related to worse survival in univariate analyses [16]. Prognostic factors from the GETUG-15 trial were used to define three prognostic subgroups of survival in hormone-naïve prostate cancer. ALP alone accounted for all the differences in survival regardless of degree of metastasis. One should be wary of drawing any conclusion from this; ADT could have been initiated up to two months before inclusion into the study, so that flare, a transient increase in ALP following ADT, could itself have increased ALP values [21]. In our multivariate analyses elevated ALP (>1.25 times upper limit of normal) was an independent prognostic factor for poor survival in the mSS 2 group, and even Score Groups 2 and 3 together.

In our study PSA level (> $233 \mu \mathrm{g} / \mathrm{l}$ ) was an independent prognostic factor for adverse outcome in patients with mSS 1, but not in those with Scores 2 or 3. In the three prognostic groups based on the SWOG 8894 trial, a PSA level >65 $\mu \mathrm{g} / \mathrm{l}$ had a major negative impact on survival, but a lower PSA level before start of treatment suggests that those patients were diagnosed at an earlier stage in the metastatic process than were the patients in our study [15]. 
A low haemoglobin was predictive of poor outcome in patients undergoing ADT in univariate [22] and multivariate [23] analyses. Low haemoglobin $(<124 \mathrm{~g} / \mathrm{L})$ was the only statistically significant independent variable associated with poor survival in patients with all three mSS. Anaemia may lead to therapy resistance either directly or by association. Hypoxia due to anaemia may contribute to treatment resistance. Several cytokines associated with anaemia may promote cancer metastases in the bone microenvironment and contribute to progress of bone metastases and mortality [24, 25].

In clinical studies high T-category [22] or high Gleason score [15] correlated significantly with poor survival. Also autopsy, routinely performed on patients dying of prostate cancer showed a strong relationship between extent of metastasis, high T-category and Gleason score[5].

Limitations. We did not have data on detailed numbers and locations of bone metastases and could therefore not say whether they were axial (pelvic bones and spine) or appendicular (long bones, skull), which has been a discriminating factor between risk groups in other trials $[9,10,26]$. At inclusion men with de novo metastatic disease and patients progressing from localised disease to metastases were not recorded separately. Most likely the population of the patients in this trial had a high proportion of men with de novo metastatic disease, which is not typical for men with prostate cancer diagnosed nowadays. Visceral and non-regional lymph node metastases were not evaluated at inclusion in this study. However, according to some studies, visceral metastasis (M1c) has a low prevalence; lung (2\%-11\%) and liver 
$(0.4 \%-3 \%)[9,10]$. The adverse predictive value is not clear. No attempt has been made to classify or quantify metastases in other sites than bone.

Strength of the study. To our knowledge this study is the first to subdivide M1b disease into three groups, based on the extent of bone metastasis, in order to explore any significant difference in overall and disease-specific survival. Our prognostic model was based on a large data set from a relatively homogeneous patient population with follow-up over a long period with sufficient event rate. We routinely used clinically relevant measurable variables, including QoL.

In conclusion, M1b disease is a heterogeneous diagnosis and more accurately defined subdivisions are required if one is to extract clinically relevant information. We have shown that different subgroups of M1b disease have different prognoses. Application of predictive factors according to our modified Soloway Score in future prospective trials will enable evaluation of more individualised treatment strategies in M1b disease. Patients with acceptable performance status and poor prognosis are a group in which studies on ADT combined with novel agents should be considered.

\section{Acknowledgement}

This study was financially supported by Ferring AB, Malmö, Sweden; Ferring Laegemidler A/S Copenhagen, Denmark; Pharmacia AB, Uppsala, Sweden, and Schering-Plough AB, Stockholm, Sweden.

Conflict of interest: The authors declare no conflict of interest. 
Appendix

Participants in the SPCG-5 trial

\section{Legend to Figures 1a and $1 b$}

Kaplan-Meier overall and disease-specific survival curves. $\mathrm{P}<0.001$. 


\section{References}

1. NPCR, National Prostate Cancer Register. http://npcrse/. 2014;http://npcr.se/wpcontent/uploads/2015/12/20150930 npcr report eng 2014.pdf.

2. Pagliarulo V, Bracarda S, Eisenberger MA, Mottet N, Schroder FH, Sternberg CN, et al. Contemporary role of androgen deprivation therapy for prostate cancer. Eur Urol. 2012;61(1):11-25.

3. Aus G, Robinson D, Rosell J, Sandblom G, Varenhorst E, South-East Region Prostate Cancer G. Survival in prostate carcinoma--outcomes from a prospective, populationbased cohort of 8887 men with up to 15 years of follow-up: results from three countries in the population-based National Prostate Cancer Registry of Sweden. Cancer. 2005;103(5):943-51.

4. Tangen CM, Hussain MH, Higano CS, Eisenberger MA, Small EJ, Wilding G, et al. Improved overall survival trends of men with newly diagnosed M1 prostate cancer: a SWOG phase III trial experience (S8494, S8894 and S9346). J Urol. 2012;188(4):1164-9. 5. Bubendorf L, Schopfer A, Wagner U, Sauter G, Moch H, Willi N, et al. Metastatic patterns of prostate cancer: an autopsy study of 1,589 patients. Hum Pathol. 2000;31(5):578-83.

6. Zafeirakis A. Scoring systems of quantitative bone scanning in prostate cancer: historical overview, current status and future perspectives. Hell J Nucl Med. 2014;17(2):136-44.

7. Soloway MS, Hardeman SW, Hickey D, Raymond J, Todd B, Soloway S, et al. Stratification of patients with metastatic prostate cancer based on extent of disease on initial bone scan. Cancer. 1988;61(1):195-202.

8. Gravis G, Fizazi K, Joly F, Oudard S, Priou F, Esterni B, et al. Androgen-deprivation therapy alone or with docetaxel in non-castrate metastatic prostate cancer (GETUG-AFU 15): a randomised, open-label, phase 3 trial. Lancet Oncol. 2013;14(2):149-58.

9. James ND, Spears MR, Clarke NW, Dearnaley DP, De Bono JS, Gale J, et al. Survival with Newly Diagnosed Metastatic Prostate Cancer in the "Docetaxel Era": Data from 917 Patients in the Control Arm of the STAMPEDE Trial (MRC PR08, CRUK/06/019). Eur Urol. 2014.

10. Sweeney CJ, Chen YH, Carducci M, Liu G, Jarrard DF, Eisenberger M, et al. Chemohormonal Therapy in Metastatic Hormone-Sensitive Prostate Cancer. N Engl J Med. 2015;373(8):737-46.

11. Hedlund PO, Ala-Opas M, Brekkan E, Damber JE, Damber L, Hagerman I, et al. Parenteral estrogen versus combined androgen deprivation in the treatment of metastatic prostatic cancer -- Scandinavian Prostatic Cancer Group (SPCG) Study No. 5. Scand J Urol Nephrol. 2002;36(6):405-13.

12. Hedlund PO, Damber JE, Hagerman I, Haukaas S, Henriksson P, Iversen P, et al. Parenteral estrogen versus combined androgen deprivation in the treatment of metastatic prostatic cancer: part 2. Final evaluation of the Scandinavian Prostatic Cancer Group (SPCG) Study No. 5. Scand J Urol Nephrol. 2008;42(3):220-9.

13. Fayers $P M$. Interpreting quality of life data: population-based reference data for the EORTC QLQ-C30. Eur J Cancer. 2001;37(11):1331-4.

14. Jonler M, Nielsen OS, Groenvold M, Hedlund PO, Damber L, Hedelin H, et al. Quality of life in patients with skeletal metastases of prostate cancer and status prior to start of endocrine therapy: results from the Scandinavian Prostate Cancer Group Study 5. Scand J Urol Nephrol. 2005;39(1):42-8. 
15. Glass TR, Tangen CM, Crawford ED, Thompson I. Metastatic carcinoma of the prostate: identifying prognostic groups using recursive partitioning. J Urol.

2003;169(1):164-9.

16. Gravis G, Boher JM, Fizazi K, Joly F, Priou F, Marino P, et al. Prognostic Factors for Survival in Noncastrate Metastatic Prostate Cancer: Validation of the Glass Model and Development of a Novel Simplified Prognostic Model. Eur Urol. 2015;68(2):196-204. 17. Klaff R, Berglund A, Varenhorst E, Hedlund PO, Jonler M, Sandblom G, et al. Clinical characteristics and quality-of-life in patients surviving a decade of prostate cancer with bone metastases. BJU Int. 2015.

18. Eton DT, Lepore SJ. Prostate cancer and health-related quality of life: a review of the literature. Psychooncology. 2002;11(4):307-26.

19. Bellardita L, Valdagni R, van den Bergh R, Randsdorp H, Repetto C, Venderbos LD, et al. How does active surveillance for prostate cancer affect quality of life? A systematic review. Eur Urol. 2015;67(4):637-45.

20. Rosenfeld B, Roth AJ, Gandhi S, Penson D. Differences in health-related quality of life of prostate cancer patients based on stage of cancer. Psychooncology. 2004;13(11):8007.

21. Nakashima J, Ozu C, Nishiyama T, Oya M, Ohigashi T, Asakura H, et al. Prognostic value of alkaline phosphatase flare in patients with metastatic prostate cancer treated with endocrine therapy. Urology. 2000;56(5):843-7.

22. Sylvester RJ, Denis L, de Voogt H. The importance of prognostic factors in the interpretation of two EORTC metastatic prostate cancer trials. European Organization for Research and Treatment of Cancer (EORTC) Genito-Urinary Tract Cancer Cooperative Group. Eur Urol. 1998;33(2):134-43.

23. Mulders PF, Dijkman GA, Fernandez del Moral P, Theeuwes AG, Debruyne FM. Analysis of prognostic factors in disseminated prostatic cancer. An update. Dutch Southeastern Urological Cooperative Group. Cancer. 1990;65(12):2758-61.

24. Beer TM, Tangen CM, Bland LB, Hussain M, Goldman BH, DeLoughery TG, et al. The prognostic value of hemoglobin change after initiating androgen-deprivation therapy for newly diagnosed metastatic prostate cancer: A multivariate analysis of Southwest Oncology Group Study 8894. Cancer. 2006;107(3):489-96.

25. Corcoran NM, Costello AJ. Interleukin-6: minor player or starring role in the development of hormone-refractory prostate cancer? BJU Int. 2003;91(6):545-53. 26. James ND, Sydes MR, Clarke NW, Mason MD, Dearnaley DP, Spears MR, et al. Addition of docetaxel, zoledronic acid, or both to first-line long-term hormone therapy in prostate cancer (STAMPEDE): survival results from an adaptive, multiarm, multistage, platform randomised controlled trial. Lancet. 2015.

27. Crawford ED, Eisenberger MA, McLeod DG, Spaulding JT, Benson R, Dorr FA, et al. A controlled trial of leuprolide with and without flutamide in prostatic carcinoma. $\mathrm{N} \mathrm{Engl} \mathrm{J}$ Med. 1989;321(7):419-24.

28. Eisenberger MA, Blumenstein BA, Crawford ED, Miller G, McLeod DG, Loehrer PJ, et al. Bilateral orchiectomy with or without flutamide for metastatic prostate cancer. $\mathrm{N}$ Engl J Med. 1998;339(15):1036-42.

29. Hussain M, Tangen CM, Berry DL, Higano CS, Crawford ED, Liu G, et al. Intermittent versus continuous androgen deprivation in prostate cancer. N Engl J Med.

2013;368(14):1314-25. 
Table 1: Baseline characteristics for the 900 study patients by modified Soloway scorea

\begin{tabular}{|c|c|c|c|c|c|c|c|c|c|}
\hline & \multicolumn{2}{|c|}{ Soloway Score 1} & \multicolumn{2}{|c|}{$\begin{array}{c}\text { Soloway Score } \\
2\end{array}$} & \multicolumn{2}{|c|}{$\begin{array}{c}\text { Soloway Score } \\
3\end{array}$} & \multirow[b]{2}{*}{$\begin{array}{c}\text { p- } \\
\text { value }\end{array}$} & \multicolumn{2}{|c|}{ Total } \\
\hline & $\mathbf{n}$ & $\%$ & $\mathbf{n}$ & $\%$ & $\mathbf{n}$ & $\%$ & & $\mathbf{n}$ & $\%$ \\
\hline All cases & 319 & 100 & 483 & 100 & 98 & 100 & - & 900 & 100 \\
\hline Median follow-up, months & 112,5 & $59.3-201.7$ & 63,3 & $36-108.5$ & 48,3 & $\begin{array}{l}32.8- \\
81.1\end{array}$ & & 75,6 & $\begin{array}{l}39.2- \\
139.3\end{array}$ \\
\hline \multicolumn{10}{|l|}{ Cause of Death } \\
\hline Prostate cancer & 187 & 66,5 & 389 & 83,8 & 75 & 78,2 & & 651 & 77,4 \\
\hline Other causes & 94 & 33,5 & 75 & 16,2 & 21 & 21,8 & - & 190 & 22,6 \\
\hline \multicolumn{10}{|l|}{ Initial treatment } \\
\hline Polyestradiol phosphate & 152 & 47,6 & 250 & 51,8 & 49 & 50 & & 451 & 50,1 \\
\hline TAB & 167 & 52,4 & 233 & 48,2 & 49 & 50 & 0,754 & 449 & 49,9 \\
\hline \multicolumn{10}{|l|}{ Age, years } \\
\hline$<65$ & 44 & 13,8 & 76 & 15,7 & 12 & 12,2 & & 132 & 14,7 \\
\hline $65-74$ & 144 & 45,1 & 231 & 47,8 & 49 & 50 & & 424 & 47,1 \\
\hline$\geq 75$ & 131 & 41,1 & 176 & 36,4 & 37 & 37,8 & 0,619 & 344 & 38,2 \\
\hline \multicolumn{10}{|l|}{ Cancer-related pain } \\
\hline No pain & 241 & 77,7 & 283 & 63,3 & 60 & 65,2 & & 584 & 68,8 \\
\hline Pain & 69 & 22,3 & 164 & 36,7 & 32 & 34,8 & $<0.001$ & 265 & 31,2 \\
\hline \multicolumn{10}{|l|}{ ECOG performance status } \\
\hline 0 & 203 & 65,7 & 253 & 57 & 53 & 57,6 & & 509 & 60,2 \\
\hline $1-2$ & 106 & 34,3 & 191 & 43 & 39 & 42,4 & 0,041 & 336 & 39,8 \\
\hline \multicolumn{10}{|l|}{ Analgesic consumption } \\
\hline Negligible & 254 & 81,9 & 273 & 61,1 & 63 & 68,5 & & 590 & 69,5 \\
\hline$\geq 1$ & 56 & 18,1 & 174 & 38,9 & 29 & 31,5 & $<0.001$ & 259 & 30,5 \\
\hline \multicolumn{10}{|l|}{ Grade of malignancy } \\
\hline WHO 1 & 52 & 16,7 & 64 & 13,5 & 18 & 19,4 & & 134 & 15,2 \\
\hline WHO 2 & 144 & 46,2 & 230 & 48,4 & 37 & 39,8 & & 411 & 46,7 \\
\hline WHO 3 & 116 & 37,2 & 181 & 38,1 & 38 & 40,9 & 0,37 & 335 & 38,1 \\
\hline \multicolumn{10}{|l|}{ T-category } \\
\hline T0-T2 & 79 & 24,8 & 84 & 17,6 & 23 & 23,7 & & 186 & 20,8 \\
\hline T3-T4 & 239 & 75,2 & 394 & 82,4 & 74 & 76,3 & 0,028 & 707 & 79,2 \\
\hline \multicolumn{10}{|l|}{ Cardiovascular comorbidity } \\
\hline None & 276 & 87,3 & 434 & 90,2 & 92 & 93,9 & & 802 & 89,6 \\
\hline Present & 40 & 12,6 & 47 & 9,8 & 6 & 6,1 & 0,128 & 93 & 10,4 \\
\hline \multicolumn{10}{|l|}{ Alkaline phosphatase } \\
\hline$<1.25 \mathrm{x}$ upper limit of normal & 272 & 86,6 & 160 & 33,9 & 15 & 15,3 & & 447 & 50,6 \\
\hline$\geq 1.25 \times$ upper limit of normal & 42 & 13,4 & 312 & 66,1 & 83 & 84,7 & $<0.001$ & 437 & 49,4 \\
\hline \multicolumn{10}{|l|}{ PSA, $\mu \mathrm{g} / \mathrm{L}$} \\
\hline$<$ median $(<233)$ & 213 & 67,2 & 206 & 42,8 & 31 & 31,6 & & 450 & 50,2 \\
\hline$\geq$ median $(\geq 233)$ & 104 & 32,8 & 275 & 57,2 & 67 & 68,4 & $<0.001$ & 446 & 49,8 \\
\hline \multicolumn{10}{|l|}{ Haemoglobin, g/L } \\
\hline$<$ median $(<124)$ & 119 & 37,8 & 265 & 55,7 & 65 & 66,3 & & 449 & 50,5 \\
\hline$\geq$ median $(\geq 124)$ & 196 & 62,2 & 211 & 44,3 & 33 & 33,7 & $<0.001$ & 440 & 49,5 \\
\hline
\end{tabular}




\begin{tabular}{|c|c|c|c|c|c|c|c|c|c|}
\hline$<$ median $(<13)$ & 141 & 46,8 & 225 & 52,2 & 44 & 51,2 & & 410 & 50,1 \\
\hline$\geq$ median $(\geq 13)$ & 160 & 53,2 & 206 & 47,8 & 42 & 48,8 & 0,354 & 408 & 49,9 \\
\hline
\end{tabular}

a Soloway scores 1-3; extent of M1b disease modified ad modum SPCG: Score $1 \leq$ size of 3 bodies of a lumbal vertebra; Score $2=$ the total area of hot spots larger than Score 1, but $<75 \%$ of the total scan; Score $3 \geq 75 \%$ of the skeleton involved.

Table 2: Baseline EORTC-30 ratings for the 900 study patients according to modified Soloway score.

\begin{tabular}{lccccccc}
\hline & \multicolumn{2}{c}{$\begin{array}{c}\text { Soloway } \\
\text { score 1 }\end{array}$} & \multicolumn{2}{c}{$\begin{array}{c}\text { Soloway } \\
\text { score 2 }\end{array}$} & \multicolumn{2}{c}{ Soloway } \\
score 3 & \\
EORTC-30 ratings & mean & sd & mean & sd & mean & sd & p-value \\
Global Health status & 64,4 & 21,7 & 52,6 & 24 & 50,5 & 25,1 & $<0.001$ \\
Functional scales & & & & & & & \\
$\quad$ Physical Functioning & 81,4 & 22,8 & 72 & 28 & 65,7 & 30,4 & $<0.001$ \\
$\quad$ Role Functioning & 94,1 & 10,7 & 90,3 & 12,8 & 89,3 & 13,4 & $<0.001$ \\
$\quad$ Emotional Functioning & 79,6 & 19,8 & 75,2 & 22,2 & 72,4 & 23,4 & 0,005 \\
Cognitive Functioning & 85,2 & 18,3 & 83 & 21,1 & 82,4 & 21,8 & 0,287 \\
$\quad$ Social Functioning & 90,7 & 16 & 82,2 & 25 & 79,3 & 26,7 & $<0.001$ \\
Symptom scales & & & & & & & \\
$\quad$ Fatigue & 27,6 & 22,7 & 41 & 27,2 & 49,5 & 25,2 & $<0.001$ \\
$\quad$ Dyspnoea & 19,5 & 23,7 & 20,8 & 25,3 & 22,7 & 27,5 & 0,557 \\
$\quad$ Nausea / vomiting & 4,3 & 12,7 & 9,3 & 17,7 & 13,6 & 19,8 & $<0.001$ \\
Pain & 21,8 & 25,7 & 41,5 & 31,3 & 45,5 & 32,9 & $<0.001$ \\
Insomnia & 20,6 & 28,3 & 27,8 & 30,7 & 32,2 & 31,5 & 0,001 \\
Appetite loss & 11,7 & 25 & 25,8 & 33,5 & 34,5 & 35,4 & $<0.001$ \\
$\quad$ Constipation & 16,1 & 25,3 & 22,5 & 30,4 & 29,5 & 31,9 & 0,001 \\
$\quad$ Diarrhoea & 7,4 & 16,7 & 6,2 & 16,7 & 9,8 & 21,7 & 0,195 \\
Financial problems & 4,2 & 16,1 & 6,5 & 18,6 & 3,9 & 13 & 0,156 \\
\hline
\end{tabular}

\section{Legend to Figures 1a and 1b}

Kaplan-Meier overall and disease-specific survival curves. $\mathrm{P}<0.001$. 


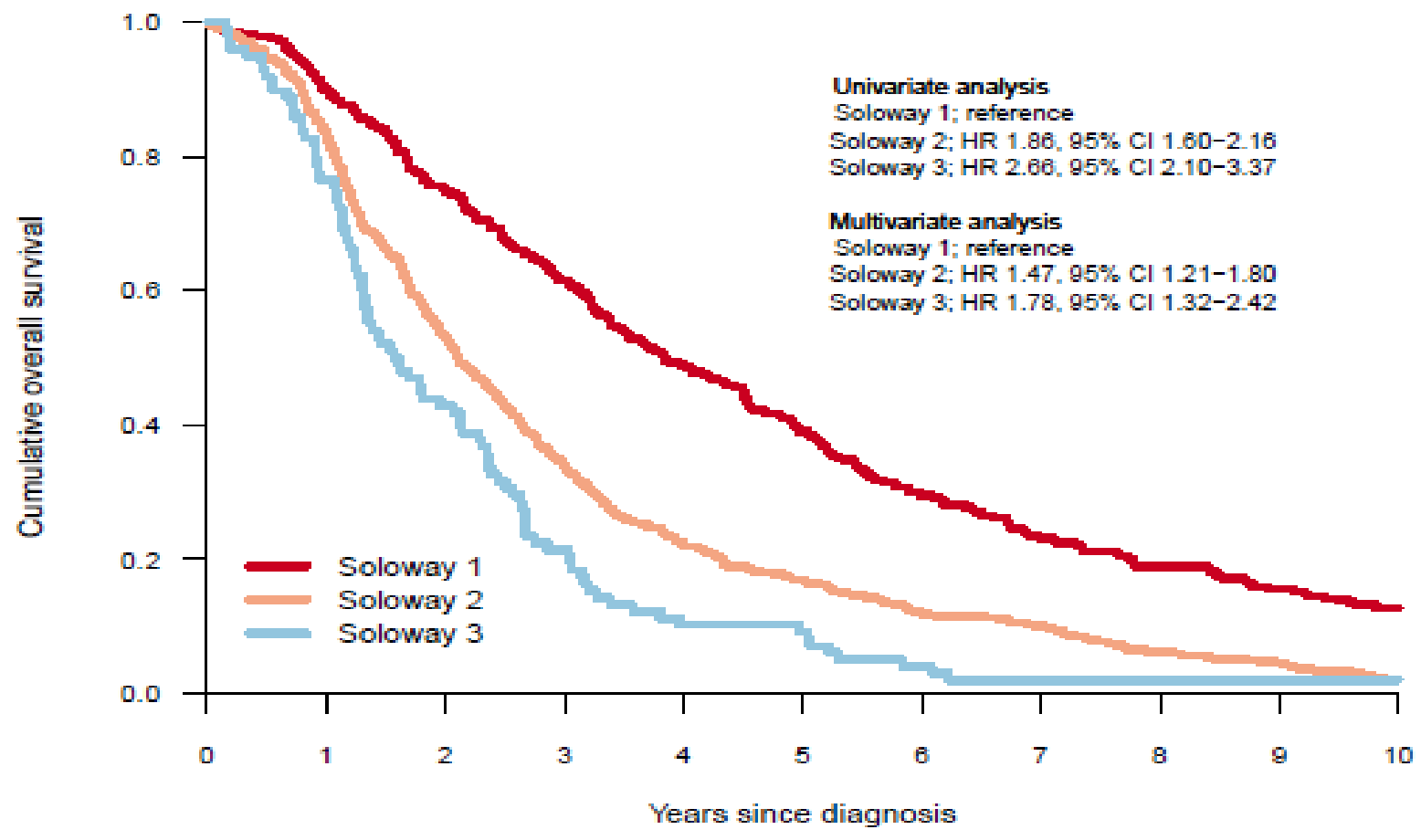

No. at risk

$\begin{array}{rrrrrrrrrrrr}\text { Soloway 1 } & 317 & 284 & 235 & 192 & 149 & 118 & 89 & 70 & 57 & 47 & 30 \\ \text { Soloway 2 } & 483 & 403 & 250 & 160 & 105 & 78 & 55 & 46 & 29 & 21 & 9\end{array}$

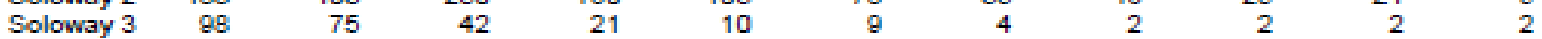

\section{Figure 1b}



No. at risk






\begin{tabular}{|c|c|c|c|c|c|c|}
\hline & Solov & $\begin{array}{l}\text { ay Score } \\
1\end{array}$ & Solo & $\begin{array}{l}\text { ay Score } \\
2\end{array}$ & Solov & $\begin{array}{l}\text { ay Score } \\
3\end{array}$ \\
\hline & aHR & $95 \% \mathrm{CI}$ & aHR & $95 \% \mathrm{CI}$ & aHR & $95 \% \mathrm{CI}$ \\
\hline \multicolumn{7}{|l|}{ ECOG performance status } \\
\hline 0 & 1.00 & ref. & 1.00 & ref. & - & - \\
\hline $1-2$ & 1,39 & $\begin{array}{l}1.02- \\
1.89\end{array}$ & 1,37 & $\begin{array}{l}1.07- \\
1.76\end{array}$ & - & - \\
\hline \multicolumn{7}{|l|}{ Analgesic consumption } \\
\hline Negligible & 1.00 & ref. & 1.00 & ref. & - & - \\
\hline$\geq 1$ & 1,44 & $\begin{array}{l}1.00- \\
2.08\end{array}$ & 1,02 & $\begin{array}{l}0.79- \\
1.31\end{array}$ & - & - \\
\hline \multicolumn{7}{|l|}{ Grade of malignancy } \\
\hline WHO 1 & 1.00 & ref. & 1.00 & ref. & - & - \\
\hline WHO 2 & 0,89 & $\begin{array}{c}0.61- \\
1.31\end{array}$ & 1,09 & $\begin{array}{c}0.78- \\
1.53\end{array}$ & - & - \\
\hline WHO 3 & 1,58 & $\begin{array}{l}1.07- \\
2.33\end{array}$ & 1,69 & $\begin{array}{l}1.20- \\
2.37\end{array}$ & - & - \\
\hline \multicolumn{7}{|l|}{ Alkaline phosphatase } \\
\hline$<1.25 \times$ upper limit of normal & 1.00 & ref. & 1.00 & ref. & - & - \\
\hline$\geq 1.25 \mathrm{x}$ upper limit of normal & 1,16 & $\begin{array}{c}0.76- \\
1.75\end{array}$ & 1,29 & $\begin{array}{l}1.02- \\
1.63\end{array}$ & - & - \\
\hline \multicolumn{7}{|l|}{ PSA, $\mu \mathrm{g} / \mathrm{L}$} \\
\hline$<$ median $(<233)$ & 1.00 & ref. & - & - & - & - \\
\hline$\geq \operatorname{median}(\geq 233)$ & 1,41 & $\begin{array}{l}1.05- \\
1.88\end{array}$ & - & - & - & - \\
\hline \multicolumn{7}{|l|}{ Haemoglobin, g/L } \\
\hline$<$ median $(<124)$ & 1.00 & ref. & 1.00 & ref. & 1.00 & ref. \\
\hline$\geq$ median $(\geq 124)$ & 0,69 & $\begin{array}{c}0.52- \\
0.91\end{array}$ & 0,77 & $\begin{array}{c}0.62- \\
0.96\end{array}$ & 0,58 & $\begin{array}{c}0.38- \\
0.89\end{array}$ \\
\hline \multicolumn{7}{|l|}{ Global Health status } \\
\hline$<$ mean $(<56.8)$ & 1.00 & ref. & 1.00 & ref. & - & - \\
\hline$\geq$ mean $(\geq 56.8)$ & 0,73 & $\begin{array}{c}0.55- \\
0.99\end{array}$ & 0,78 & $\begin{array}{c}0.63- \\
0.98\end{array}$ & - & - \\
\hline
\end{tabular}


Table 4: Stratification of prostate cancer patients with hormone-naïve M1 disease in selected clinical trials on Androgen Deprivation Treatment (ADT).

\begin{tabular}{|c|c|c|c|c|c|c|}
\hline $\begin{array}{l}\text { Trial; Reference No. } \\
\text { First author, year }\end{array}$ & $\begin{array}{l}\text { No. of } \\
\text { patients }\end{array}$ & Treatment & $\begin{array}{l}\text { Disease spread } \\
\text { at base line } \\
\text { according to } \\
\text { TNM } \\
\text { classification }{ }^{\text {a }} \\
\text { No. of patients } \\
\text { (\%) }\end{array}$ & $\begin{array}{l}\text { Stratification } \\
\text { according to } \\
\text { extent of the } \\
\text { disease No. of } \\
\text { patients (\%) }\end{array}$ & $\begin{array}{l}\text { Stratification } \\
\text { according to } \\
\text { other variables }\end{array}$ & Survival \\
\hline $\begin{array}{l}\text { SWOG S8494; } 1 \text { Crawford } \\
\text { ED 1989[27] }\end{array}$ & 603 & $\begin{array}{l}\text { ADT } \\
\text { Leuprolide +/- } \\
\text { Flutamide }\end{array}$ & $\begin{array}{l}\text { M1a } 108 \text { (18) } \\
\text { M1b; na (77) } \\
\text { M1c; } 51 \text { (8) }\end{array}$ & $\begin{array}{l}\text { Minimal; } 82 \\
\text { (14) } \\
\text { severe; } 521(86)\end{array}$ & $\begin{array}{l}\text { Performance } \\
\text { status } \\
0-2 \text { vs } 3\end{array}$ & $\begin{array}{l}\text { Benefit in minimal } \\
\text { disease }\end{array}$ \\
\hline $\begin{array}{l}\text { SWOG S8894; } 2 \\
\text { Eisenberger MA 1998[28] }^{\text {b }}\end{array}$ & 1385 & $\begin{array}{l}\text { ADT } \\
\text { Orchiectomy +/- } \\
\text { Flutamide }\end{array}$ & $\begin{array}{l}\text { M1a; } 304(22) \\
\text { M1b; } 1368(92) \\
\text { M1c; } 218(16)\end{array}$ & $\begin{array}{l}\text { Minimal; } 287 \\
\text { (21) } \\
\text { extensive; } 1998 \\
\text { (79) }\end{array}$ & $\begin{array}{l}\text { Performance } \\
\text { status } \\
0 \text { - } 2 \text { vs } 3\end{array}$ & $\begin{array}{l}\text { Not enhanced benefit } \\
\text { in minimal disease }\end{array}$ \\
\hline $\begin{array}{l}\text { SWOG S9346; } 3 \\
\text { Hussain M 2013[29] }^{\text {b }}\end{array}$ & 1535 & $\begin{array}{l}\text { ADT } \\
\text { Intermittent vs } \\
\text { continuous }\end{array}$ & $\begin{array}{l}\text { M1 a,b,c; } \\
\text { 1535(100) } \\
\text { M1c;103 (15) }\end{array}$ & $\begin{array}{l}\text { Minimal;798 } \\
\text { (52) } \\
\text { extensive } 737 \\
(48)\end{array}$ & $\begin{array}{l}\text { Performance } \\
\text { status } \\
0-1 \text { vs } 2 \\
\text { no therapy vs } \\
\text { neo-adjuvant } \\
\text { ADT } \\
\text { or Finasteride }\end{array}$ & Statistically inconclusive \\
\hline $\begin{array}{l}\text { GETUG-AFU 15; } 4 \\
\text { Gravis G 2014[8] }\end{array}$ & 385 & $\begin{array}{l}\mathrm{ADT}+/- \\
\text { Docetaxel }\end{array}$ & $\begin{array}{l}\text { M1a; } 23 \text { (6) } \\
\text { M1b; } 311(81) \\
\text { M1c; } 51 \text { (13) }\end{array}$ & $\begin{array}{l}\text { Glass risk } \\
\text { groups }^{c} \\
\text { good;191 ((50) } \\
\text { intermediate; } \\
111(29) \\
\text { poor; } 83 \text { (21) }\end{array}$ & $\begin{array}{l}\text { Performance } \\
\text { status } \\
0 \text { vs } 1-3 \\
\text { PSA }<65 \text { vs }>65 \\
\text { Gleason score }<8 \\
\text { vs } \geq 8\end{array}$ & $\begin{array}{l}\text { Overall survival } \\
\text { significantly } \\
\text { longer in the good } \\
\text { prognosis group, } \\
\text { shorter in poor prognosis } \\
\text { group; } \\
\text { no difference between } \\
\text { intermediate } \\
\text { and poor prognosis group }\end{array}$ \\
\hline $\begin{array}{l}\text { ECOG E 3805;5 } \\
\text { CHAARTED } \\
\text { Sweeney CJ 2015[10 }]^{\mathrm{d}}\end{array}$ & 790 & $\begin{array}{l}\text { ADT +/- } \\
\text { Docetaxel }\end{array}$ & $\begin{array}{l}\text { M1a+ M1c; } 336 \\
\text { (43) } \\
\text { M1b; } 790(100) \\
\text { M1c; } 123(16)\end{array}$ & $\begin{array}{l}\text { Low volume; } \\
\text { 276; (35) } \\
\text { high volume; } \\
514 \text { (65) }\end{array}$ & $\begin{array}{l}\text { Prior adjuvant } \\
\text { ADT }<12 \\
\text { months vs } \\
>12 \text { months }\end{array}$ & $\begin{array}{l}\text { Benefit more pronounced } \\
\text { in the high volume group, } \\
\text { in the low volume group } \\
\text { median survival not } \\
\text { reached }\end{array}$ \\
\hline $\begin{array}{l}\text { Medical Research Council } \\
\text { STAMPEDE; } 6 \\
\text { James DJ 2015[9] }\end{array}$ & 917 & $\begin{array}{l}\text { ADT } \\
\text { Standard of care }\end{array}$ & $\begin{array}{l}\text { M1a; } 277(30) \\
\text { M1b; } 811(88) \\
\text { M1c; } 59(6)\end{array}$ & $\begin{array}{l}\text { Metastases } \\
\text { grouping: } \\
\text { bone only; } 574 \\
\text { (62), } \\
\text { bone and soft } \\
\text { tissue } 237 \text { (26), } \\
\text { soft tissue only } \\
106 \text { (12) }\end{array}$ & None & Statistically inconclusive \\
\hline $\begin{array}{l}\text { Scandinavian Prostate Cancer } \\
\text { Group } \\
\text { SPCG 5;7 } \\
\text { Hedlund PO 2008[12] }\end{array}$ & 915 & $\begin{array}{l}\text { ADT } \\
\text { Parenteral } \\
\text { Oestrogen vs } \\
\text { Total Androgen } \\
\text { Blockade }^{\mathrm{e}}\end{array}$ & $\begin{array}{l}\text { M1a; not } \\
\text { available } \\
\text { M1b; } 915 \text { (100) } \\
\text { M1c; not } \\
\text { available }\end{array}$ & None & $\begin{array}{l}\text { Performance } \\
\text { status } \\
0-1 \text { vs } 2, \\
\text { Alkaline } \\
\text { phosphatase } \\
<1.25 x \text { the upper } \\
\text { limit of normal } \\
\geq 1.25 x \text { the upper } \\
\text { limit of normal, } \\
\text { cardiovascular } \\
\text { morbidity }\end{array}$ & No differences \\
\hline
\end{tabular}

a TNM Classification of Malignant Tumours 1992 and later; M1 distant metastasis; M1a non-regional lymph nodes; M1b bones; M1c other sites. ADT, Androgen Deprivation Treatment.

${ }^{\mathrm{b}}$ Defined in the South West Oncology Group (SWOG) trials; minimal or extensive/severe. Minimal: absence of metastasis in the ribs, long bones, skull, or soft tissue, other than lymph node involvement. Extensive/severe: appendicular skeletal involvement, visceral (lung, lever) or both; performance status 3.

c Glass risk groups; Good: without appendicular bone lessons and without visceral involvement. Intermediate: with appendicular bone lessons and/or visceral involvement, performance status 0 ; Gleason score $\geq 8$. Poor: with appendicular bone lesions, performance status $\geq 1$; PSA $\geq 65$.

${ }^{\mathrm{d}}$ Low volume: $<4$ bone lesions in pelvis bones and/or vertebra bodies. High volume: visceral metastases or $\geq 4$ bone lesions with at least one beyond the vertebra bodies and pelvis (appendicular).

e Total Androgen Blockade: medical or surgical castration in combination with non-steroid antiandrogen. 


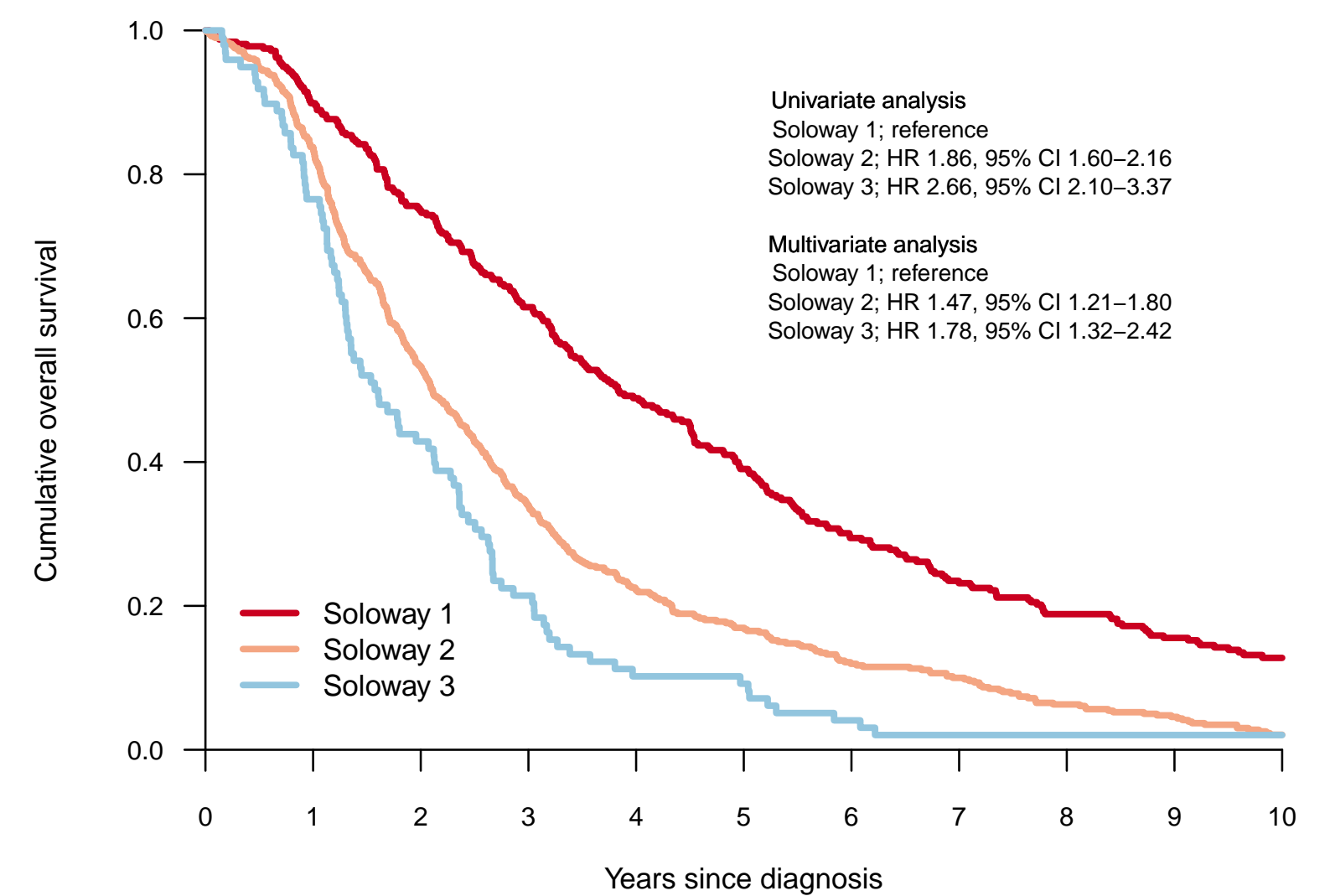

No. at risk

$\begin{array}{lrrrrrrrrrrr}\text { Soloway 1 } & 317 & 284 & 235 & 192 & 149 & 118 & 89 & 70 & 57 & 47 & 30 \\ \text { Soloway 2 } & 483 & 403 & 250 & 160 & 105 & 78 & 55 & 46 & 29 & 21 & 9 \\ \text { Soloway 3 } & 98 & 75 & 42 & 21 & 10 & 9 & 4 & 2 & 2 & 2 & 2\end{array}$

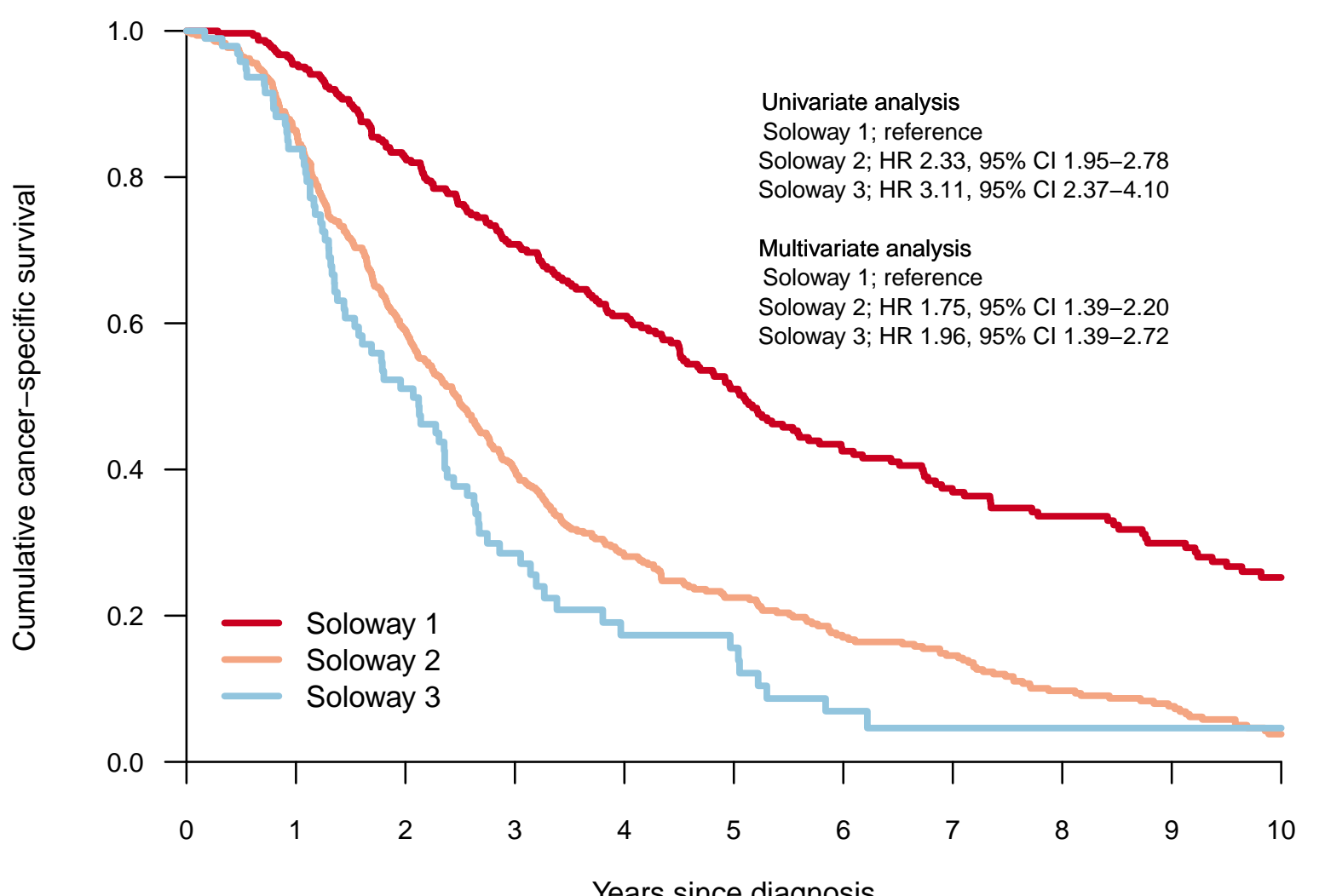

No. at risk

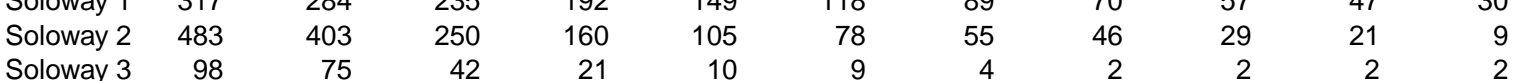

